\title{
Relationship between pulmonary function, functional independence, and trunk control in patients with stroke
}

\author{
Relação entre função pumonar, independência functional e controle de tronco em \\ pacientes após acidente vascular cerebral \\ Rafaela Sant'anna dos SANTOS', Sara Carolina Fontoura DALL'ALBA', Soraia Genebra Ibrahim \\ FORGIARINI'2, Daniele ROSSATO ${ }^{3}$, Alexandre Simões DIAS ${ }^{3,4}$, Luiz Alberto FORGIARINI JUNIOR
}

\begin{abstract}
Stroke often leads to abnormalities in muscle tone, posture, and motor control that may compromise voluntary motor function, thus affecting the motor control required for maintaining the synergy of both peripheral and respiratory muscles. Objective: To evaluate respiratory muscle strength, pulmonary function, trunk control, and functional independence in patients with stroke and to correlate trunk control with the other variables. Methods: This was a cross-sectional study of patients diagnosed with stroke. We assessed respiratory muscle strength, trunk control as assessed by the Trunk Impairment Scale, spirometric variables, and the Functional Independence Measure. Results: Forty-four patients were included. Pulmonary function and respiratory muscle strength were significantly lower than predicted for the study population, and the mean Trunk Impairment Scale score was 14.3 points. The following significant correlations were found between the variables: trunk control vs. maximal inspiratory pressure $(r=0.26, p<0.05)$; trunk control vs. forced vital capacity $(r=0.28, p<0.05)$; trunk control vs. forced expiratory volume in one second $(r=0.29, p<0.05)$, and trunk control vs. the Functional Independence Measure $(r=0.77, p<0.05)$. Conclusion: The present study showed that respiratory muscle strength, pulmonary function, functional independence, and trunk control are reduced in patients diagnosed with stroke.
\end{abstract}

Keywords: Spirometry; manometry; stroke; Physical therapy specialty.

\section{RESUMO}

Acidente vascular cerebral (AVC) frequentemente leva a anormalidades no tônus muscular, postura e controle motor que podem comprometer a função motora voluntária, afetando o controle motor necessário para manter a sinergia dos músculos periféricos e respiratórios. Objetivo: Avaliar a força muscular respiratória, a função pulmonar, o controle do tronco e a independência funcional em pacientes com AVC e correlacionar o controle do tronco com as demais variáveis. Métodos: Este foi um estudo transversal, incluindo pacientes diagnosticados com AVC. Avaliamos a força muscular respiratória, o controle do tronco avaliado pela escala de comprometimento de tronco, as variáveis espirométricas e a medida de independência funcional. Resultados: Quarenta e quatro pacientes foram incluídos. A função pulmonar e a força muscular respiratória foram significativamente menores do que o previsto para a população estudada, e o escore médio do escala de comprometimento de tronco foi de 14,3 pontos. As seguintes correlações significativas foram encontradas entre as variáveis: controle do tronco vs. pressão inspiratória máxima $(r=0,26, p<0,05)$; controle do tronco vs capacidade vital forçada $(r=0,28, p<0,05)$; controle do tronco versus volume expiratório forçado no primeiro segundo $(r=0,29, p<0,05)$ e controle do tronco vs. medida de independência funcional ( $r=0,77, p<0,05)$. Conclusão: 0 presente estudo demonstrou que a força muscular respiratória, a função pulmonar, a independência funcional e o controle do tronco estão diminuídos em pacientes diagnosticados com AVC.

Palavra-chave: Espirometria; manovacuometria; acidente vascular cerebral; fisioterapia.

\footnotetext{
${ }^{1}$ Centro Universitário Metodista, Porto Alegre, RS, Brasil;

${ }^{2}$ Centro Universitário Metodista, Curso de Fisioterapia, Porto Alegre, RS, Brasil;

${ }^{3}$ Hospital de Clínicas de Porto Alegre, Serviço de Fisioterapia, Porto Alegre, RS, Brasil;

${ }^{4}$ Universidade Federal do Rio Grande do Sul, Programas de Pós-graduação em Ciências Pneumológicas e Ciências do Movimento Humano , Porto Alegre, RS, Brasil. 5Universidade La Salle, Curso de Fisioterapia e Programa de Pós-graduação em Saúde e Desenvolvimento Humano, Canoas, RS, Brasil.
}

Rafaela Sant'anna dos Santos (iD) https://orcid.org/0000-0001-9238-7836; Sara Carolina Fontoura Dall'Alba (iD) https://orcid.org/0000-0002-4995-3086; Soraia Genebra Ibrahim Forgiarini (iD) https://orcid.org/0000-0002-8688-4999; Daniele Rossato (iD https://orcid.org/0000-0001-8245-5903; Luiz Alberto Forgiarini Junior (iD) https://orcid.org/0000-0002-6706-2703; Alexandre Simões Dias (iD https://orcid.org/0000-0002-0609-4779

Correspondence: Luiz Alberto Forgiarini Junior; Av. Vítor Barreto, 2288 - Canoas - RS, 92010-000 RS, Brasil; E-mail: forgiarini.luiz@gmail.com

Conflict of interest: There is no conflict of interest to declare.

Received 03 September 2018; Received in final form 12 December 2018; Accepted 21 January 2019. 
Stroke is one of the most common causes of longterm disability worldwide and a major public health problem ${ }^{1}$. Each year, nearly 11 million people worldwide have a stroke, of whom five million remain functionally limited ${ }^{2,3}$. According to the World Health Organization, stroke is a rapidly-progressing syndrome characterized by clinical signs of focal or global brain function impairment of possible vascular origin and lasting for at least 24 hours ${ }^{4}$. Nearly $50 \%$ to $70 \%$ of affected patients recover functional independence and, within six months, nearly $50 \%$ still present with hemiparesis/hemiplegia ${ }^{2}$.

Stroke often leads to abnormalities in muscle tone, posture, and motor control that may compromise voluntary motor function, thus affecting the motor control required for maintaining the synergy of both peripheral and respiratory muscles ${ }^{1,5}$. Pulmonary infections are the most prevalent complications, causing the death of $30 \%$ of patients before hospital discharge $e^{6,7}$. Nevertheless, the lack of strength in muscles of the trunk could impact in respiratory function.

The effect of stroke on the respiratory system depends on the injured structures, and maintenance of normal ventilation requires functional components of the neuromuscular system to be intact. Ventilatory disorders occur when the disease affects the nervous system, muscle paths and/or rib cage movements ${ }^{8,9}$. Therefore, we hypothesized that stroke patients present with several sequelae usually leading to deficits in functional capacity and pulmonary function. Hence, the objectives of this study were to assess respiratory muscle strength, pulmonary function, trunk control, and functional independence in patients with stroke, and to correlate trunk control with the other variables.

\section{METHODS}

This was a cross-sectional study conducted at the Department of Neurology of Hospital de Clínicas de Porto Alegre from November 2014 to May 2015. The research project was approved by the Research Ethics Committee of Hospital de Clínicas de Porto Alegre (process no. 14-0582). Patients who met the inclusion criteria and agreed to participate in the study provided written informed consent prior to their participation.

This study included male and female patients, over 18 years of age, clinically diagnosed with stroke by the neurology team. Exclusion criteria were an inability to perform study-related procedures, presence of respiratory tract metastases, hemodynamic instability, and altered cognitive status compromising the patient's ability to perform the tests. Patients with pulmonary complications such as bronchoaspiration and pneumonia during hospitalization were not included. After inclusion in the study, all patients were simultaneously assessed for functional independence, trunk control, respiratory muscle strength, and pulmonary function.
Data on age, weight, height, body mass index, length of hospital stay, time elapsed after stroke, type of stroke, and number of previous strokes were collected directly from medical records. The patients eligible to participate in the study were evaluated by the clinical team and underwent physiotherapy treatment. All patients were hemodynamically stable, with controlled blood pressure, no syncope, and absence of tumors or clinical diseases that could interfere with the evaluation process.

Physical functioning was assessed using the Functional Independence Measure scale, an instrument designed to quantitatively assess the burden of care required for someone to perform a series of everyday motor and cognitive activities, such as self-care, transfer, locomotion, sphincter control, communication, and social cognition, including memory, social interaction, and problem solving. Each category is given a score from 1 (total dependence) to 7 (complete independence). This yields a total score ranging from 18 to $126^{10}$.

The trunk control was assessed using the Trunk Impairment Scale, an instrument comprising seven main domains scored from 0 (minimum) to 21 (maximum) points. These domains assessed the perception and impairment of trunk verticality, abdominal muscle strength, trunk rotation muscle strength, and righting reflex, all of which were assessed bilaterally. The Trunk Impairment Scale was administered by the same examiner, providing a score that indicated the patient's status at the time of assessment ${ }^{11}$.

The respiratory muscle strength was assessed using an analog manometer (Marshall Town, MVM 120, USA) to measure maximal inspiratory pressure (MIP) and maximal expiratory pressure (MEP). Measures were assessed with patients in the sitting position using a nose clip and a mouthpiece positioned firmly between their lips. The MIP was acquired at residual volume, and the MEP at total lung capacity. In both cases, measures were taken in triplicate or more, the highest of which was considered for analysis, and differences between measures could not be greater than $10 \%^{2,4,12,13}$.

For pulmonary function analysis, forced expiratory volume in one second (FEV1), forced vital capacity (FVC), and the Tiffeneau index (TIFF) (FEV1/FVC) were measured through spirometry (One Flow micro spirometer, Clement Clarke International, Edinburgh, Scotland ${ }^{14}$. Their predicted values were also calculated based on the equation proposed by Derumond et al. ${ }^{15}$, to assess levels of pulmonary function in a healthy population. This equation was compared with two other equations in a previous study that found no significantly relevant differences between equations ${ }^{16}$.

Sample size was calculated based on a previous study conducted by our group ${ }^{17}$, resulting in a sample size of at least 38 patients for an alpha of $5 \%$ and a power of 80 . Continuous data were expressed as mean \pm standard deviation, and categorical variables as absolute and percentage values. The Shapiro-Wilk test was used to assess the normality of data distribution. Pulmonary function and maximal respiratory 
pressures were compared using the Student's t test, and the correlation between trunk control and the other variables was assessed using Pearson's correlation. The level of significance was set at $5 \%$.

\section{RESULTS}

Fifty-four patients participated in the study from November 2014 to May 2015. There was a predominance of females $(65.7 \%)$, the mean patient age was $59.4 \pm 12.2$ years, and ischemic stroke was the most prevalent type (92.1\%).

The demographic characteristics of the population are shown in Table 1. Results for pulmonary function, respiratory muscle strength, and trunk control are presented in Table 2, and functional independence as assessed by the Functional Independence Measure is described in Table 3.

We also assessed the correlation of trunk control with pulmonary function, respiratory muscle strength, and functional independence. Trunk control was found to be significantly

Table 1. Demographic characteristics of the study population.

\begin{tabular}{lc} 
Variables & $\mathrm{n}=44$ \\
\hline Sex, female & $25(65.7)$ \\
Age, years & $59.4 \pm 12.2$ \\
Weight, $\mathrm{kg}$ & $73.9 \pm 15.1$ \\
Height, $\mathrm{m}$ & $1.6 \pm 0.1$ \\
Body Mass Index, $\mathrm{kg} / \mathrm{m}^{2}$ & $27.8 \pm 5.3$ \\
Length of stay, days & $14.6 \pm 7.1$ \\
\hline Stroke, $\mathrm{n}(\%)$ & \\
\hline \multicolumn{1}{l}{ Ischemic } & $52(92.1)$ \\
\hline \multicolumn{1}{l}{ Hemorrhagic } & $3(7.9)$ \\
Stroke time, days & $14.9 \pm 26.3$ \\
\hline Values expressed as mean \pm standard deviation or number (percentage).
\end{tabular}

Table 2. Evaluation of pulmonary function, respiratory muscular strength and trunk control.

\begin{tabular}{lccc} 
Variable & $\begin{array}{c}\text { Value } \\
\text { obtained }\end{array}$ & $\begin{array}{c}\text { Predicted } \\
\text { value }\end{array}$ & p-value \\
\hline FEV1 & $1.9 \pm 0.9$ & $3.3 \pm 0.6$ & \\
FVC & $2.5 \pm 0.9$ & $3.8 \pm 0.7$ & \\
$\begin{array}{l}\text { Tiffeneau Index } \\
\text { Expiratory flow } \\
\text { peak }\end{array}$ & $88.9 \pm 12.5$ & & \\
MIP, $\mathrm{cmH}_{2} \mathrm{O}$ & $47.4 \pm 29.1$ & $91.1 \pm 13.9$ & 0.001 \\
MEP, $\mathrm{cmH}_{2} \mathrm{O}$ & $36.1 \pm 18.6$ & $93.3 \pm 18.8$ & 0.001 \\
$\begin{array}{l}\text { Trunk Impairment } \\
\text { Scale }\end{array}$ & $14.4 \pm 5.8$ & & \\
\hline
\end{tabular}

Data expressed as mean \pm standard deviation. FEV1: forced expiratory volume in the first second; FVC: forced vital capacity; Tiffeneau Index - relationship between FEV1/FVC; MIP: maximum inspiratory pressure; MEP: maximum expiratory pressure/ $\mathrm{cmH}_{2} \mathrm{O}$ : centimeter of water. correlated with MIP $(r=0.26, p<0.05)$, FVC $(r=0.28, p<0.05)$, FEV1 $(r=0.29, p<0.05)$, and the Functional Independence Measure $(r=0.77, \mathrm{p}<0.05)$ (Figure).

\section{DISCUSSION}

Trunk control has a primary function in pulmonary mechanics-when diaphragmatic function is compromised in individuals after stroke, it is perceived that muscular paresis leads to unilateral hypoventilation and consequent decrease of pulmonary complacency, with greater elastic and nonelastic resistance of the lung, which fails to maintain lung volumes and decreases ventilation and perfusion capacity. In the present study, most of participants showed restrictive ventilatory disorder $(81.6 \%)$, characterized by impairment of total lung capacity and vital capacity, demonstrating that respiratory biomechanics is altered in patients with stroke, as well as thoracic and pulmonary compliance. This data corroborates the finding between the Trunk Impairment Scale and spirometric data, confirming the findings in the literature, which demonstrate the relationship between a decrease in pulmonary capacity and hemiparesis presented by individuals, and this may occur because the trunk flexor and extensor muscles directly interfere in respiratory mechanics and trunk stabilization ${ }^{18,19}$.

Regarding sociodemographic data and risk factors for cerebrovascular injury, the mean age of our patients was 59.4 years, corresponding to the age group at the highest risk of stroke in Brazil, which includes individuals older than 55 years of age ${ }^{12}$. The incidence of stroke increases the risk, showing a two-fold increase for every 10 years of age beyond $55^{7}$. Additionally, most patients were classified as overweight according to their body mass index and were female, both of which are important risk factors for stroke ${ }^{13}$. Together with these factors, other modifiable risk factors for cerebrovascular diseases in this population have been reported in the literature, such as high levels of blood cholesterol, high blood pressure, diabetes, and smoking ${ }^{14,15}$.

The mean length of hospital stay, for our patients, was 14.6 days, similar to that reported in a study conducted in a

Table 3. Evaluation of functionality through the Functional Independence Measure.

\begin{tabular}{lc}
\hline Variables & $\mathrm{n}=44$ \\
\hline Self Care & $29.0 \pm 11.4$ \\
Sphincter Control & $12.2 \pm 3.3$ \\
Transfers & $13.0 \pm 7.1$ \\
Locomotion & $6.4 \pm 4.0$ \\
Communication & $6.4 \pm 4.0$ \\
Social Cognition & $12.1 \pm 2.8$ \\
\hline Total & $91.2 \pm 26.4$ \\
\hline
\end{tabular}


A

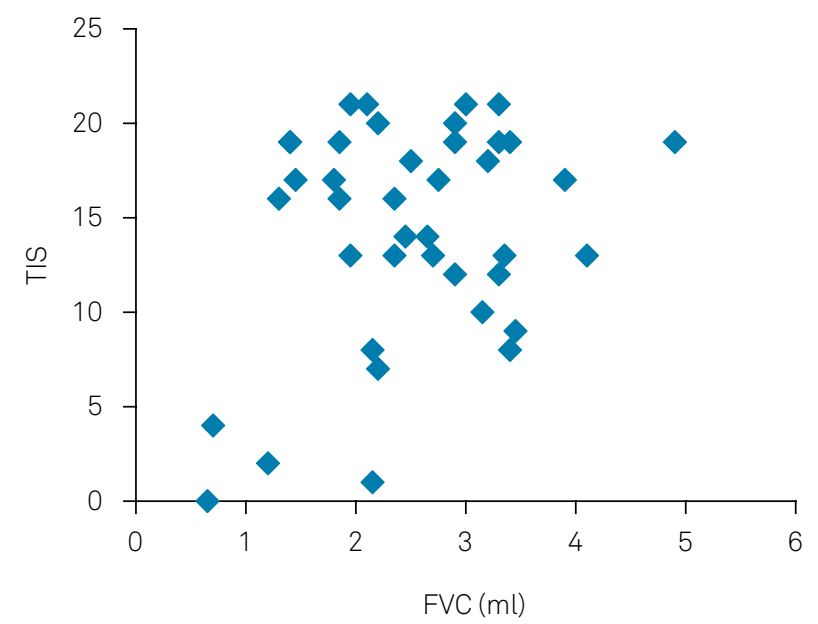

C

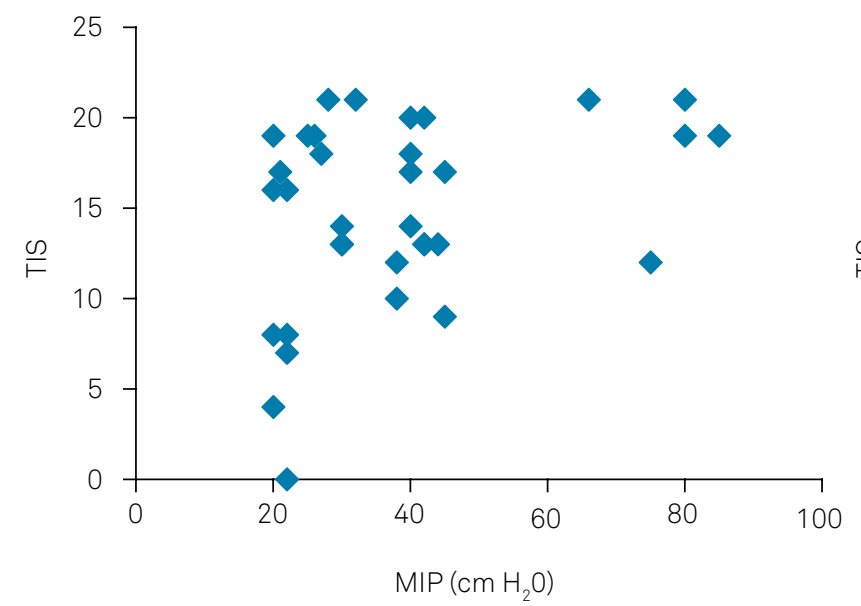

B

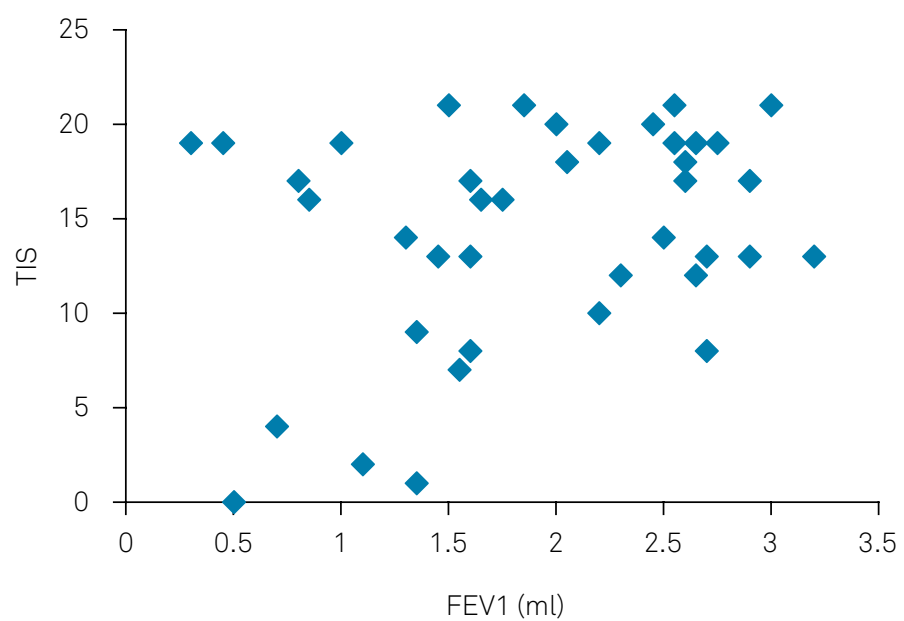

D

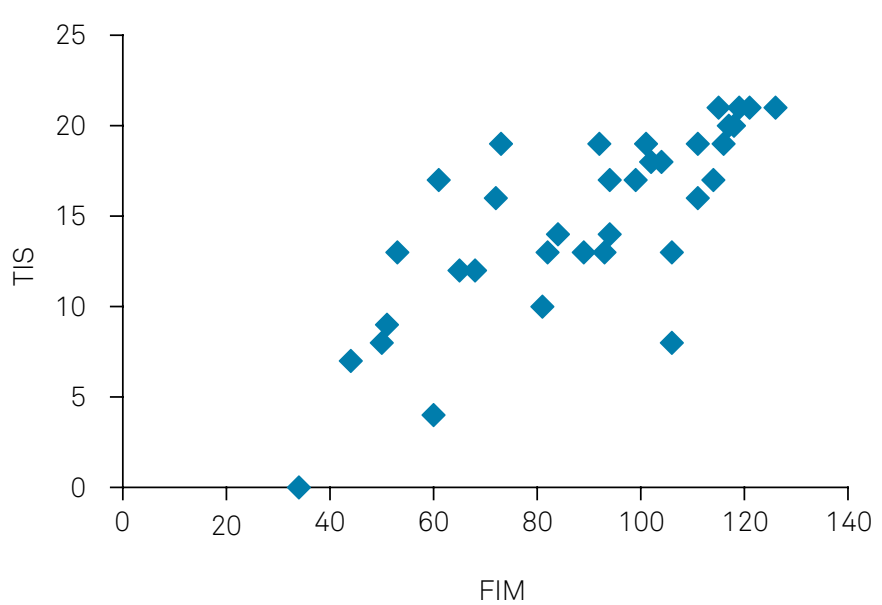

Figure. Correlation between the Trunk Impairment Scale (TIS) and forced vital capacity (FVC) $(A-r=0.28 ; p<0.05)$; forced expiratory volume in the first second (FEV1) $(B-r=0.29, p<0.05)$; maximal inspiratory pressure $(\mathrm{MIP})(\mathrm{C}-r=0.34, \mathrm{p}<0.05)$ and the Functional Independence Measure (FIM) (D - $r=0.77, p<0.05)$.

neurology ward (16.8 days $)^{17}$. In the present study, $92 \%$ of the patients were diagnosed with ischemic stroke. This percentage was higher than that in previous Brazilian studies (53 to $85 \%)^{16,17}$, which may be related to our treatment regimen for patients with hemorrhagic stroke, who remain in the intensive care unit for a longer time.

The mean MIP and MEP were lower than predicted for our patients, thus corroborating findings from the literature, such as those by Meneghetti et al. ${ }^{12}$, who also found mean MIP and MEP lower than predicted for the Brazilian population ( $62.7 \mathrm{cmH}_{2} \mathrm{O}$ and $69.8 \mathrm{cmH}_{2} \mathrm{O}$, respectively). These results suggest that the patients showed reduced respiratory muscle strength (diaphragmatic and abdominal dysfunction) and, therefore, their rehabilitation program should include respiratory muscle training ${ }^{12}$.

Similarly, pulmonary function measures were lower than predicted for our sample, which is in agreement with previous studies showing that pulmonary function was reduced in stroke patients assessed by spirometry ${ }^{16,17,20}$.
Some studies also found that impaired respiratory muscles and pulmonary function may have a direct impact on the cough mechanism, as the compression phase of this mechanism involves the activation of the diaphragm, chest and abdominal wall muscles ${ }^{21,22}$.

The mean Trunk Impairment Scale score in our patients (14.3 points) may be considered a fairly good result, considering that this score ranges from 0 to 21 points, with 0 being the worst result and 21 the best. We also observed that trunk control was weakly correlated with the FVC and FEV1 ( $\mathrm{r}=$ 0.28 and $r=0.29$, respectively), which indicated that musculoskeletal changes experienced by hemiplegic or hemiparetic patients affected pulmonary biomechanics ${ }^{23}$. This was especially so if these changes involved the flexor and extensor muscles of the trunk, as they have a key role in chest expansion, diaphragm excursion, and cough efficiency $y^{24,25}$.

The correlation of trunk control and MIP, although weak $(r=0.34 ; p<0.05)$, provided evidence of the relationship between muscular postures and respiratory muscle 
strength $^{26}$. Previous studies evaluating the latter in hemiparetic patients have demonstrated that respiratory muscle strength may compromise trunk control and directly interfere with respiratory biomechanics.

Yoon et al..$^{22}$ found reduced spirometric values in stroke patients and a correlation between these values and activities of daily living. This resulted from weakened intercostal muscles and increased chest wall rigidity, which decreased movements of the rib and lowered the distending pressure that expands the lungs, ultimately leading to reduced pulmonary capacity ${ }^{22}$. These changes could be explained by impairments in total pulmonary capacity and vital capacity, indicating that respiratory biomechanics were deficient in these patients, as well as chest and lung compliance ${ }^{23}$. This deficiency eventually limited pulmonary ventilation and confirmed that ventilatory disorders could occur in neurological diseases affecting the neuromuscular path or the rib cage even if there was no specific pulmonary involvement or lesion?.

The functionality evaluated by the Functional Independence Measure showed that the patients had reduced capacity to perform activities of daily living with complete independence. A systematic review aiming to assess the disease severity and functional capacity using the Functional Independence Measure in stroke patients revealed that, based on the studies included in the review, this condition affected patient's lives by causing limitations and disability, both in acute and chronic phases, often leading to moderate or severe dependence and increasing the complexity of the rehabilitation process ${ }^{27}$.

Additionally, we observed an association between trunk control and functional independence, as patients with greater postural control gained the stability required to reproduce functional movements. This was because axial muscles supported anti-gravitational postures and stabilized the body for limb mobilization ${ }^{28}$. A study conducted by Karatas et al. ${ }^{29}$ found a correlation of muscle weakness in trunk flexion and extension with locomotion and transfer domains of the Functional Independence Measure, showing the importance of axial stability movements for the development of limb functionality ${ }^{29}$.Other studies have observed that trunk control is important for balance, gait, and functional independence as assessed by the Functional Independence Measure $^{30,31,32}$.Future studies should prospectively evaluate patients to assess trunk control and functionality and further establish the causal relationship between the variables.

In conclusion, stroke patients showed reduced pulmonary function, respiratory muscle strength, and functional independence, and there was a strong correlation between trunk control and physical functioning.

\section{References}

1. Britto R, Rezende N, Marinho K, Torres J, Parreira V, TeixeiraSalmela L. Inspiratory muscle training in choronic stroke survivors: a randomized controlled trial. Arch Phys Med Rehabil. 2011 Feb;92(2):184-90.

2. Jandt SR, Caballer RMDS, Forgiarini Junior LA, Dias AS. Correlation between trunk control, respiratory muscle strength and spirometry in patients with stroke: an observational study. Physiother Res Int. 2011 Dec;16(4):218-24. https://doi.org/10.1002/pri.495

3. Pontes-Neto OM, Silva GS, Feitosa MR, Figueiredo NL, Fiorot JA Jr, Rocha TN, et al. Stroke awareness in Brazil: alarming results in a community-based study. Stroke. 2008;39(2):292-6. https://doi.org/10.1161/STROKEAHA.107.493908

4. Pompeu SMAA, Pompeu JE, Rosa M, Silva MR. [Correlation between motor function, balance and respiratory muscular strength after stroke]. Rev Neurocienc. 2011;19(4):614-20. Portuguese.

5. Nelles G, Spiekermann G, Julptner M. Reorganization of sensory and motor systems in hemiplegia stroke patients: a positrom emission tomography study. Stroke. 1999 Aug;30(8):1510-6. https://doi.org/10.1161/01.STR.30.8.1510

6. Ward K, Seymow J, Steier J, Jolley CJ, Polkey MI, Kalra L, Moxham J. Acute ischalmic hemispheric stroke is associated with impairment of reflex in addition to votuntary cough. Eur Respir J. 2010 Dec;36(6):1383-90. https://doi.org/10.1183/09031936.00010510

7. Heuschmann PU, Kolominsky-Rabas PL, Misselwitz B, Hermanek P, Leffmann C, Janzen RW, et al. Predictors of in-hospital mortality and attributable risks of death after ischemic stroke. Arch Intern Med. 2004 Sep;164(16):1761-8. https://doi.org/10.1001/archinte.164.16.1761

8. Howard RS, Rudd AG, Wolfe CD, Williams AJ. Pathophysiological and clinical aspects of breathing after stroke. Postgrad Med J. 2001 Nov;77(913):700-2. https://doi.org/10.1136/pmj.77.913.700
9. Le Foll-de Moro D, Tordi N, Lonsdorfer E, Lonsdorfer J. Ventilation efficiency and pulmonary function after a wheelchair interval-training program in subjects with recent spinal cord injury. Arch Phys Med Rehabil. 2005 Aug;86(8):1582-6. https://doi.org/10.1016/j.apmr.2005.03.018

10. Riberto M, Miyazaki MH, Jucá SS, Sakamoto H, Pinto PP, Battistella LR. Validação da versão brasileira da medida de independência funcional. Acta Fisiatr. 2004;11(2):72-6. https://doi.org/10.5935/0104-7795.20040003

11. Lima NM, Rodrigues SY, Fillipo TM, Oliveira R, Oberg TD, Cacho EW. [Brazilian version of the Trunk Impairment Scale: a reliability study in post-stroke subjects]. Fisioter Pesqui. 2008 ago-set;15(3):248-53. Portuguese. https://doi.org/10.1590/S1809-29502008000300006

12. Meneghetti CH, Figueiredo VE, Guedes CA, Batistela ACT. [Evaluation of respiratory muscle strength in stroke patients]. Rev Neurocienc. 2011;19(1):56-60. Portuguese.

13. Tsukamoto HF, Picinatto AE, Cavalini CA, Bortolloti LF. [Analysis of functional independence, quality of life, respiratory muscle strength and thoracic mobility in hemiparetic patients submitted to a rehabilitation program: case studies]. Semina. 2010 Jan/Jun;31(1):63-9. https://doi.org/10.5433/1679-0367.2010v31n1p63

14. Pereira CAC. Consenso de espirometria.J Pneumol. 2002 Oct.;28(Supl 3).

15. Drumond SC, Fontes MJF, Assis I, Duarte MA, Lamounier JA, Orlandi LCL, et al. Comparison of three sets of reference equations for spirometry in children and adolescents with distinct body mass indices. J Bras Pneumol. 2009 Maio;35(5):415-22. https://doi.org/10.1590/S1806-37132009000500005 
16. Silva FC, Silva SM, Sampaio LMM, Corrêa JCF, Corrêa FI. [Relationship between motor recovery and respiratory muscle strength of acute and chronic emi-paretic stroke patients]. Ter Man. 2012;10 (48). Portuguese.

17. Jandt SR, Caballer RMS, Forgiarini LAJ, Dias AS. Correlation between trunk control, respiratory muscle strength and spirometry in patients with stroke: an observational study. Physiother Res Int. 2011 Dec;16(4):218-24. https://doi.org/10.1002/pri.495

18. De Troyer A, Zegers De Beyl D, Thirion M. Function of the respiratory muscles in acute hemiplegia. Am Rev Respir Dis. 1981 Jun;123(6):631-2. https://doi.org/10.1164/arrd.1981.123.6.631

19. Przedborski S, Brunko E, Hubert M, Mavroudakis N, de Beyl DZ. The effect of acute hemiplegia on intercostal muscle activity. Neurology. 1988 Dec;38(12):1882-4. https://doi.org/10.1212/WNL.38.12.1882

20. Zhou Z, Vincent F, Salle JY, Antonini MT, Aliamus V, Daviet JC. Acute stroke phase voluntary cough and correlation with maximum phonation time. Am J Phys Med Rehabil. 2012 Jun;91(6):494-500. https://doi.org/10.1097/PHM.0b013e31824fa66a

21. II Diretrizes Brasileiras no Manejo da Tosse Crônica.J Bras Pneumol. 2006; 32 (Supl 6):S403-46.

22. Yoon J, Park J, Lee D, Roh H. Comparisons of respiratory function and activities of daily living between spinal cord injury and stroke patients and normal elderly people.J Phys Ther Sci. 2011;24(6):465-9. https://doi.org/10.1589/jpts.24.465

23. Scanlan CL, Wilkins RL, Stoller J. Fundamentos da teoria respiratória de Egan. 7a ed. São Paulo: Manole; 2000.

24. Fernandes FE, Martins SRG, Bonvent J. Efeitos do treinamento muscular respiratório por meio do manovacuômetro e do Treshold Pep em pacientes hemiparéticos hospitalizados. IFMBE Proc. 2008;18:1199-202.
25. Teixeira-Salmela LF, Parreira VF, Britto RR, Brant TC, Inácio ÉP, Alcântara TO, et al. Respiratory pressures and thoracoabdominal motion in community-dwelling chronic stroke survivors. Arch Phys Med Rehabil. 2005 Oct;86(10):1974-8. https://doi.org/10.1016/j.apmr.2005.03.035

26. Fugl-Meyer AR, Linderholm H, Wilson AF. Restrictive ventilatory dysfunction in stroke: its relation to locomotor function. Scand $J$ Rehabil Med Suppl. 1983;9:118-24.

27. Gadelha ID, Ribeiro KS. Nivel de severidade e capacidade funcional de sujeitos pós-AVE e o acesso à reabilitação. ConScientiae Saúde. 2016;15(1):135-42. https://doi.org/10.5585/conssaude.v15n1.5725

28. Tsuji T, Liu M, Hase K, Masakado Y, Chino N. Trunk muscles in persons with hemiparetic stroke evaluated with computed tomography. J Rehabil Med. 2003 Jul;35(4):184-8. https://doi.org/10.1080/16501970306126

29. Karatas M, Cetin N, Bayramoglu M, Dilek A. Trunk muscle strength in relation to balance and functional disability in unihemispheric stroke patients. Am J Phys Med Rehabil. 2004 Feb;83(2):81-7. https://doi.org/10.1097/01.PHM.0000107486.99756.C7

30. Verheyden G, Vereeck L, Truijen S, Troch M, Herregodts I, Lafosse $C$, et al. Trunk performance after stroke and the relationship with balance, gait and functional ability. Clin Rehabil. 2006 May;20(5):451-8. https://doi.org/10.1191/0269215505cr955oa

31. Duarte E, Marco E, Muniesa JM, Belmonte R, Diaz P, Tejero $M$, et al. Trunk control test as a functional predictor in stroke patients. J Rehabil Med. 2002 Nov;34(6):267-72. https://doi.org/10.1080/165019702760390356

32. Carvalho PC, Santos ALD, Silva SM, Cavalli SS, Corrêa JCF, Corrêa FI. Avaliação da qualidade de vida antes e após terapia com dança sênior em pacientes hemiparéticos pós-AVE. Conscientiae saúde 2012;11(4):573-9. https://doi.org/10.5585/conssaude.v11n4.3284 